\title{
Evaluation of Heavy and Trace Metals in Fingernails of Young School Children and Adults in Ilorin, Kwara State, Nigeria
}

\section{${ }^{1}$ OKORO, HK; ${ }^{1}$ ALAO, ST; ${ }^{1}$ ADEBAYO, GB $;{ }^{2}$ BASHEER, KA}

\author{
1. Department of Industrial Chemistry, Faculty of Physical Sciences University of Ilorin, Kwara State, Nigeria. \\ 2. Central Research Laboratory, University of Lagos, Akoka, Lagos State, Nigeria \\ Corresponding author's email: okoroowo@yahoo.com; hkoadeola@gmail.com
}

\begin{abstract}
Fingernail samples of young school children and selected adults were collected with respect to sex and ages in Ilorin Kwara state. The aim of this study was to determine the level of heavy metals $(\mathrm{Fe}$ and $\mathrm{Cu}$ ) and trace elements $(\mathrm{Mg}$ and $\mathrm{K}$ ) in the-fingernails of young school children and some selected adults using atomic absorption spectrophotometer techniques for metal analysis. Soil samples were collected from the automobile workshop of the adults examined. Sample collection and preparation were carried out using standard procedures. The result of the study showed presences of heavy metal in the fingernails of young school children and Adults in order of $\mathrm{Fe}>\mathrm{Cu}(0.43-6.85 \mu \mathrm{g} / \mathrm{g}, \mathrm{Cu} 0.01-0.08 \mu \mathrm{g} / \mathrm{g})$ and for essential trace metals $\mathrm{Mg}>\mathrm{K}(\mathrm{Mg} 0.47-1.97 \mu \mathrm{g} / \mathrm{g}, \mathrm{K} 0.25-1.32 \mu \mathrm{g} / \mathrm{g})$ respectively From the result of the study, $\mathrm{Fe}$ show higher concentration while $\mathrm{Cu}$ shows the least level. Metal concentration is higher in young school children when compared with Adults, statistical analysis show that there was significant difference between the concentrations of heavy metal in fingernails of young school children when compared with Adults. For soil samples analyzed at the automobile workshop, the concentrations of heavy metals range between $\mathrm{Fe}(344.97 \mu \mathrm{g} / \mathrm{g}) ; \mathrm{Zn}(2.4442 \mu \mathrm{g} / \mathrm{g}) ; \mathrm{Pb}$ $(0.93667 \mu \mathrm{g} / \mathrm{g}), \mathrm{Cr}(0.535 \mu \mathrm{g} / \mathrm{g})$ and $\mathrm{Cu}(0.5017 \mu \mathrm{g} / \mathrm{g})$ respectively. (O) JASEM
\end{abstract}

KEYWORDS: Heavy metals, fingernails, children and adults, AAS

\section{http://dx.doi.org/10.4314/jasem.v19i2.20}

\section{Introduction}

A heavy metal is any metal or metalloid of environmental concern. The term originated with reference to the harmful effects of cadmium, mercury and lead, all of which are denser than iron. It has since been applied to any other similarly toxic metal, or metalloid such as arsenic, regardless of density (Abdulrehman et al., 2008). Heavy metals may exist as a natural component of the earth's crust. They cannot be biodegraded or destroyed and to some extent, may enter our bodies through food, drinking water and air. As trace elements, some heavy metals such as copper, selenium, zinc are essential to maintain the metabolism of the human body, however, at higher concentration; they may lead to poisoning (Nowak and Chmielnicka, 2000).

Heavy metal poisoning could results for instance, from drinking water contamination (e.g. lead pipes), high ambient air concentration near the heavy metal emission sources, or through intake via the food chain (Nowak and Chmielnicka, 2000). It has been established in Nigeria that both human beings and animals are unnecessarily over-exposed to numerous environmental hazards, often as a result of gross inefficiency and negligence. These poor environmental conditions have resulted in increasingly deteriorating health condition as well as drastic reduction in the expectancy, contrary to what obtains in the developed world (Mehra and Juneja, 2005). Nail tissue is rich in fibrous proteins that contain keratins as cysteine residues. Their roots are highly influenced by health status of the cells, whereas blood and other body fluids give transient concentrations, human nails provide a continuous record of elemental concentration.

Nail growth in human is a continuous process throughout life, about 0.05-1.2 mm per week, with the toe nails growing at a slower rate of $30-50 \%$ and thus provides a longer integration period for the metals. Furthermore, blood and other body fluids are not suitable to analyze levels of $\mathrm{Cd}$ because the metal exists briefly in the medium. Moreover, nails are easier to sample, transport and store since they do not require any external conditions unlike body fluids that are prone to contaminations (Kumar et al., 2013). 
According to various studies, anyone could be poisoned by toxic metals but the most risk group are children under the age of six due to their not fully developed central nervous system and other organs, having more hand to mouth activities, untimely outdoor activities, not fully developed hygienic habits and active metabolism. Studies have shown that heavy metals such as lead, copper, cobalt, cadmium and zinc enter the fingernails through all the above listed activities (Kumar et al., 2013). The aim and objective of this study is to determine the level of heavy metals in the fingernails of young school children and some selected adult in Ilorin, Kwara State, Nigeria to evaluate the level of exposure to these metals.

\section{MATERIALS AND METHODS}

Sample collection: The experiment was carried out at the University Primary School, University of Ilorin and Tanke Oke-odo, Ilorin, Kwara state, Nigeria. For ethical and legal reasons, the participation of the school children and mechanics was voluntary. Appropriate permits and approval were obtained prior to the survey. Having been granted the approval and permit, field visit and sampling began. The experiment was done on the $6^{\text {th }}$ of January 2014 for the Mechanics at Oke-odo while that of the young school children was done on the $13^{\text {th }}$ of January 2014. Nine (9) Adults within the age range of 25-30 year old were selected at Oke-odo with all of them giving their consent to carry on with the collection of their nails. Twenty (20) children under the age of 312 years were randomly selected with informed consent from their parents/guardians. Prior to the selection of the pupils, questionnaires were given to some pupils of the school so as to get permission. Each subject was given a labeled razor blade and tissue paper. The nails of the subjects were cleaned with methylated spirit, medicated soap, rinsed with distilled water, then dried with tissue paper. Fingernail were cut from the subject and kept in a labeled plastic bottle closed, until they were ready for the analysis.

Procurement of Requisite Detail of Subject: Questionnaires provide information about the following variables: ages, sex, residence and quality of food and information about food sources was obtained through multiple choice questions. Based on the recommendation of (WHO) world health organization.

Samples Pre-Treatment: To remove the external contamination from the nails, the pre-digestion technique was applied such that it will remove only the surface external contamination without extracting metals from the samples or depositing metals on them. According to Harrison and Tyree, 1971 detergent washing reduced the element concentrations more than the organic solvent washing. However, for heavy metals, washing procedures do not essentially influence their concentrations because of the strong complex with the disulfide groups in the keratin proteins (David et al., 2012). Therefore, acetone was used in this study as a washing liquid to remove the external contaminants. This washing method was further evaluated (Baba et al., 2009; Bada and Oyegbami, 2012) and their studies showed that there was no loss of heavy metals during washing with acetone.

Atomic Absorption Spectrophotometry (model 210 VGP) was used for this study. Water used throughout the analytical procedures was distilled, weighing balance used, nitric acid and acetone .The plastic bottles were cleaned with non- ionic liquid soap rinsed with distilled water, soaked overnight in 1:1 nitric acid and rinsed thoroughly with distilled water. All the glass wares used in the study were decontaminant by soaking them overnight in $5 \% \mathrm{HNO}_{3}$ and rinsed thoroughly in distilled water. They were oven dried at $105^{\circ} \mathrm{C}$ for 30 min and stored safely in a desiccator (Raj and Ram 2013)

Sample preparation for AAS analysis: The nails were pre-cleaned in a previously cleaned beaker for 15 minutes in distilled acetone (3/5, v/v) for $24 \mathrm{hr}$. Then, they were washed several times with distilled water and dried in an oven at $80^{\circ} \mathrm{C}$ for 30 minutes. The oven-dried samples were protected in polyethylene bags prior to further analysis. An oven-dried $0.1 \mathrm{~g}$ of each nail sample was digested with $10 \mathrm{ml} \mathrm{HNO}_{3} / \mathrm{HCl}(6: 1)$ acid mixture and placed at room temperature overnight, to prevent foaming. They were ashed on a hot plate near dryness. A $2 \mathrm{ml}$ amount of $19 \% \mathrm{HNO}_{3}$ was then added and the residue after heating was dissolved with distilled water and completed to $100 \mathrm{ml}$ using $100 \mathrm{ml}$ standard flask. They were then put in plastic bottles, labeled and stored under lock and key waiting AAS analysis.

Sample analysis: The metal ion concentration in samples was determined using Atomic Absorption Spectrophotometry; Standard solutions were prepared from single-element stock solutions of $1000 \mathrm{ppm}$. All chemical materials used in this work were of analytical grade and blank samples were prepared to avoid any contamination.

Collection and digestion of soil samples: Samples were collected from four points in mechanic workshop in Ilorin. The soil samples was kept in a polythene bags and transported to the laboratory. In the laboratory, samples were placed in a desiccator for an I hour, it was sieved through $0.425 \mathrm{~mm}$ and then oven dried at $105 \mathrm{oC}$ for 2 hours. After oven drying, $1.0 \mathrm{~g}$ of the fine portion 
of the dust was then digested using $3 \mathrm{ml}$ mixture of aqua regia acid at $95^{\circ} \mathrm{C}$ for at least one hour until white fume appeared. The extract was cooled and was filtered through a whart man filter paper. The filtrate was then made up to mark to a volume of $50 \mathrm{ml}$ in the volumetric flask with distilled water and analyzed for metal using AAS.

\section{RESULTS AND DISCUSSION}

The concentration of heavy metals from school children and Adults is represented in figure 1. The mean concentration of $\mathrm{Mg}$ ranged between 1.5-0.8 $\mu \mathrm{g} / \mathrm{g}, \mathrm{K}$ ranged from $0.5-0.8 \mu \mathrm{g} / \mathrm{g}, \mathrm{Fe}$ ranged from $0.6-6.0 \mu \mathrm{g} / \mathrm{g}$ and $\mathrm{Cu}$ ranged from $0-0.2 \mu \mathrm{g} / \mathrm{g}$ respectively in that orders. The level of the metals was in the following order $\mathrm{Fe}>\mathrm{Mg}>\mathrm{K}>\mathrm{Cu}$ (Figure 2). Mean concentration of heavy metals in fingernails sample from school children and mechanics with respect to age group. Metal concentration is higher in school children when compared to that of adults. Therefore, statistical analysis shows significant difference between the concentrations of heavy metals in the fingernail samples of children when compared to adult.

Table 1: Mean concentration of heavy metals in the fingernails of young school children and adults.

\begin{tabular}{ccccccc}
\hline METALS & 3-4yrs & 7-8yrs & 9-10yrs & 9-10yrs & 12yrs & 25-30yrs \\
\hline Mg & $0.47 \pm 0.12$ & $1.36 \pm 0.13$ & $0.75 \pm 0.35$ & $1.97 \pm 0.98$ & $1.25 \pm 0.06$ & $1.87 \pm 0.74$ \\
$\mathbf{K}$ & $0.37 \pm 0.05$ & $0.34 \pm 0.06$ & $1.32 \pm 1.40$ & $0.25 \pm 0.07$ & $0.27 \pm 0.06$ & $0.51 \pm 0.11$ \\
$\mathbf{F e}$ & $6.59 \pm 0.75$ & $0.52 \pm 0.01$ & $6.85 \pm 0.19$ & $0.43 \pm 0.121$ & $0.52 \pm 0.12$ & $1.66 \pm 0.50$ \\
$\mathbf{C u}$ & $0.04 \pm 0.01$ & $0.02 \pm 0.01$ & $0.03 \pm 0.01$ & $0.02 \pm 0.01$ & $0.01 \pm 0.01$ & $0.08 \pm 0.04$ \\
\hline
\end{tabular}

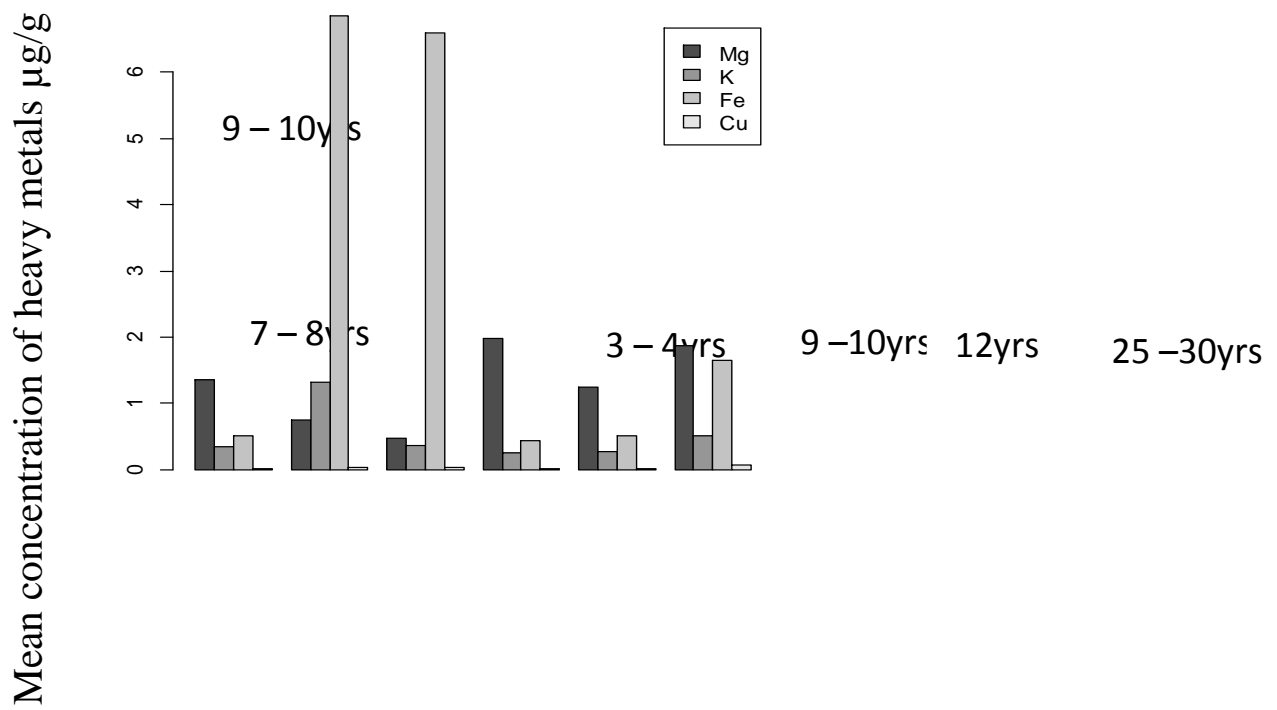

Fig 1: Mean concentration of heavy metals in fingernails samples collected from school children and Adults with respect to age group in Ilorin.

Result and discussion on soil samples.: The mean concentration of heavy metals in the soil samples are summarized in Table 2. The concentrations of heavy metals range between $\mathrm{Fe}(344.97 \mu \mathrm{g} / \mathrm{g}) ; \mathrm{Zn}(2.4442$ $\mu \mathrm{g} / \mathrm{g}) ; \mathrm{Pb}(0.93667 \mu \mathrm{g} / \mathrm{g}), \mathrm{Cr}(0.535 \mu \mathrm{g} / \mathrm{g})$ and $\mathrm{Cu}$ $(0.5017 \mu \mathrm{g} / \mathrm{g})$. Fe has the highest concentration among other metals. There was variation in the values of concentrations recorded. High concentrations recorded could be attributed to anthropogenic factors. These elements have been produced by alteration and distribution via wind blow. The result indicates that soil or road dust plays an important role in the concentration buildup of the road side dust near automobile workshops.

Table 2: Concentration of heavy metals in the soil samples in the automobile workshop

\begin{tabular}{lllll}
\hline Metals & Site A & Site B & Site C & Site D \\
\hline $\mathrm{Fe}$ & $388.03 \pm 51.4$ & $294.88 \pm 72.4$ & $316.75 \pm 29.9$ & $380.22 \pm 70.5$ \\
$\mathrm{Cu}$ & $0.26 \pm 0.02$ & $0.375 \pm 0.11$ & $0.63 \pm 0.11$ & $0.74 \pm 0.64$ \\
$\mathrm{Zn}$ & $1.58 \pm 0.07$ & $2.133 \pm 0.89$ & $3.45 \pm 0.36$ & $2.61 \pm 0.04$ \\
\hline
\end{tabular}

${ }^{l}$ OKORO, HK; ${ }^{l}$ ALAO, ST; ${ }^{l}$ ADEBAYO, GB; ${ }^{2}$ BASHEER, KA 


\begin{tabular}{lllll}
\hline $\mathrm{Cr}$ & $0.63 \pm 0.10$ & $0.397 \pm 0.13$ & $0.53 \pm 0.07$ & $0.57 \pm 0.06$ \\
$\mathrm{~Pb}$ & $0.64 \pm 0.139$ & $0.71 \pm 0.36$ & $1.62 \pm 0.80$ & $0.77 \pm 0.37$ \\
\hline
\end{tabular}

Table 3: Descriptive statistics of heavy metals concentration in soil samples $\mu \mathrm{g} / \mathrm{g}$

\begin{tabular}{llllll}
\hline Variables & $\mathbf{F e}$ & $\mathbf{C u}$ & $\mathbf{Z n}$ & $\mathbf{C r}$ & $\mathbf{P b}$ \\
\hline Obs & 12 & 12 & 12 & 12 & 12 \\
Means & 344.92 & 0.5017 & 2.4442 & 0.535 & 0.9367 \\
Std dev & 65.879 & 0.3328 & 0.8238 & 0.12154 & 0.5736 \\
Min & 201.08 & 0.24 & 1.24 & 0.25 & 0.38 \\
Max & 446.51 & 1.43 & 3.84 & 0.74 & 2.54 \\
\hline
\end{tabular}

Correlation coefficient and factor analysis: Pearson's correlation coefficient can be used to measure the degree of correlation between logarithms of the heavy metals data. The correlations of heavy metals in soil samples from Ilorin are depicted in Table 3. All the metal pairs showed positive relations except for pairs $\mathrm{Fe}-\mathrm{Pb}, \mathrm{Cu}-\mathrm{Cr}$ and $\mathrm{Cr}-\mathrm{Pb}$ which were significant at $95 \%$ and/or higher confidence level. $\mathrm{Fe}, \mathrm{Cr}$ and $\mathrm{Zn}$ significantly correlated with each other (0.847 and 0.781 ) at $95 \%$ or higher confidence level, which may indicate a common origin, such as automobile emission. The principal component matrix analysis is given in Table 4. Principal Component Analysis (PCA) was carried out to ascertain the possible contributing factors towards the metal concentrations and thereby determine which metals have a common origin. $\mathrm{Zn}$ and $\mathrm{Pb}$. This factor may indicate a source of mixed

Table 4: Correlation matrix for the heavy metal concentrations origin including air-borne emissions originated from mobile vehicle, road side dust. The second factor

\begin{tabular}{|c|c|c|c|c|}
\hline $\mathrm{Fe}$ & $\mathrm{Fe}$ & $\begin{array}{l}\mathrm{Cu} \\
0.097\end{array}$ & $\begin{array}{l}\mathrm{Zn} \\
0.057\end{array}$ & $\begin{array}{l}\mathrm{Cr} \\
0.847^{* *}\end{array}$ \\
\hline $\mathrm{Cu}$ & 0.097 & 1 & 0.486 & -0.030 \\
\hline $\mathrm{Zn}$ & .057. & .486 & 1 & .071 \\
\hline $\mathrm{Cr}$ & $.847^{* *}$ & -.030 & .071 & 1 \\
\hline & -.036 & .195 & $.781^{* *}$ & -.025 \\
\hline
\end{tabular}

**. Correlation is significant at the 0.01 level (2tailed).

Table 5: Factor loadings and communalities

\begin{tabular}{ccc}
\multicolumn{3}{c}{ of heavy metals } \\
\hline Variable & Factor1 & Factor2 \\
Eigenvalues & 2.033 & 1.836 \\
$\begin{array}{c}\text { Explained Variances } \\
(\%)\end{array}$ & 40.653 & 36.73 \\
\hline $\mathrm{Fe}$ & & \\
$\mathrm{Cu}$ & 0.4323 & 0.7795 \\
$\mathrm{Zn}$ & 0.4301 & -0.1759 \\
$\mathrm{Cr}$ & 0.8305 & -0.3698 \\
$\mathrm{~Pb}$ & 0.4137 & 0.7890 \\
& 0.6829 & -0.4110 \\
\hline
\end{tabular}

Two factors that have eigenvalues $>1$ were extracted. The total variance explained by these two factors was $77.4 \%$. The first factor explains the greatest amount of variance $(40.653 \%)$ which is predominantly loaded by
$\mathrm{Pb}(36.73 \%)$ is characterized by high loading of $\mathrm{Cr}$ and $\mathrm{Fe}$ -0.0 moderately by $\mathrm{Pb}$, which is characteristically

0.1 identified with vehicles and road dust. $\mathrm{Pb}$ also has 0.195 distributed within the second with moderate load .78 ylue. This factor is indicative of automobile emission
sources.

Cqmparison of results with other studies: For finger nails analysis: The study was carried out among young school children with age ranged from 3-10 years and also among automobile workers with age ranged from 25- 30 years of age. Heavy metals obtained in fingernails or in this study were $\mathrm{Cu}$ and $\mathrm{Fe}$. The result obtained in this study is quite different from result obtained from similar study done in Maiduguri metropolis (Atayese et al., 2009). From other related studies carried out in Parkstan (Fakayode, and Olu-Owolabi, 2003) (10) and Egypt (Sukumar and Subramaman, 2003), the order of concentration of heavy were $\mathrm{Cu}>\mathrm{Zn}>\mathrm{Co}>\mathrm{Mn}$ $>\mathrm{Cr}>\mathrm{Cd}>\mathrm{As}>\mathrm{Ni}$.

The level of Fe in this study increase with ages among male and female, this is similar to study done by Atayese et al., 2009. The level of Fe was higher in male than in female which is also in support of study done in Maiduguri metropolis (Atayese et al., 2009). The level of iron obtained in this study is lowered (within the range of 0.6-6.0 $\mu \mathrm{g} / \mathrm{g}$ ) compared to level obtained in Maiduguri metropolis $(1.23-11.34 \mu \mathrm{g} / \mathrm{g})$. This may be due to different work, nutritional status, 
and geographical difference. Apparently, the concentration of $\mathrm{Fe}$ is much lower than the values recorded by Atayase et al., 2006 which may be attributed to nutritional status and geographical difference and apparently the level of $\mathrm{Cu}$ increase with ages among male and decrease with age among female.

This study is similar to that of Egypt (Sukumar and Subramaman, 2003) and in contrast to study done in Australian where $\mathrm{Cu}$ is absent in fingernails.In the case of Maiduguri metropolis and Pakistan, the concentration of heavy metals $(\mathrm{Fe}, \mathrm{Cu}, \mathrm{Zn}, \mathrm{Cr}$ and $\mathrm{Pb})$ was determined in the soil collected from the automobile workshop. Concentration of $\mathrm{Fe}$ was found to be highest in all the samples analyzed followed by $\mathrm{Zn}, \mathrm{Pb}, \mathrm{Cu}$ and $\mathrm{Cr}$ in that order. $\mathrm{Fe}$ has the highest concentration than other metals examined. This result is similar to the findings of Wilhelm et al., 2007 and Wilhelm and Hafner, 1997. When compared this results with other related study carried out in USA, China and Poland, Fe was not found. Highest concentration was recorded for zinc at point 1-3 while the lowest concentration was recorded at point. The results from Table 2 showed that iron had the highest concentration ranging from $294.88-388.03 \mu \mathrm{g} / \mathrm{g}$ and $\mathrm{Cu}$ with the list concentration ranging from $0.26-0.74 \mu \mathrm{g} / \mathrm{g}$. This is similar to the finding carried out by Wilhelm and Hafner, 1997 (1440-69750 mg/kg) and the reason for high iron concentration may be due to natural origin of the study area, wear and tear of certain part of vehicle moving on the road, $\mathrm{Cr}(0.39-0.63 \mu \mathrm{g} / \mathrm{g})$ and $\mathrm{Pb}(0.64-$ $1.62 \mu \mathrm{g} / \mathrm{g})$ have considerable low concentration compared to $\mathrm{Zn}(1.58-3.45 \mu \mathrm{g} / \mathrm{g})$.

The result obtained was similar to what is recorded by NEPAL in Birungi, et al., 2009 and in contrast to study obtained in Ilorin where the concentration of $\mathrm{Zn}(0-889$ $\mathrm{mg} / \mathrm{kg}$ ) was lower than lead (69.4-1180.2 $\mathrm{mg} / \mathrm{kg}$ ) which may be depend on the traffic volume. Though there may be other factors contributing to these metals in soil samples, which may due to battery waste and car tyres. All the metals pairs in this study does not have good correlation with each other but in contrast with the study obtained in Nepal that correlate with each other $(\mathrm{p}<0.05)$ (Birungi, et al., 2009).

The results obtained from the soil samples analysis as presented in Table 2, when compared with the finger nails results it appears that highest concentration was recorded for $\mathrm{Fe}$ in both studies. The soil pollution by iron could be the source of more Fe recorded in adult's finger nails.

Conclusions: The result of the study shows that there is presence of heavy metals in the fingernails of the young school children and the concentration of heavy metals recorded was in the order $\mathrm{Fe}>\mathrm{Cu}$ and essential trace metals it was $\mathrm{Mg}>\mathrm{K}$ This is due to their not fully developed central nervous system and other organs, more hand to mouth activities and untimely outdoor activities. While the presence of heavy metals in the fingernails of the selected adults were in the range of $\mathrm{Mg}>\mathrm{Fe}>\mathrm{K}>\mathrm{Cu}$ and this is due to chronic exposure to environmental pollution. The high value recorded for iron in the soil sample analyzed may be due to anthropogenic activities such as automobile emission, wind blow, traffic and splitting of oil on the road by automobiles.

\section{REFERENCES}

AbdulrehmanF .I , J. C. Akan, Z. M. chellube and M Waziri (2008) Levels of Heavy metals in human hair and nail samples from Maiduguri Metropolis, Borno stateNigeria. . 143(1-3); 6774.

Nowak B. and Chmielnicka, J. (2000) Relationship of lead and cadmium to essential elements in hair, teeth and nails of environmentally exposed people. Toxicological Environment Safe 46: 265-274.

Mehra, R. and Juneja, M. (2005). Finger nails as biological indices of metal exposure, Department of Pure and Applied Chemistry, Mallershi, Dayan and Saraswati University. Journal of Bioscience 30: 253-257

Kumar V, Abbas Ak and Aster JC 2013,Environmental and Nutritional diseases, in V Kumar, Ak Abbas and JC Aster (eds), Robbins Basic Pathology, $9^{\text {th }}$ ed, Elsevier, Philadelphia, PA,ISBN 978-14377-1781-5.

David O.Olukanni, David O. Adeoye (2012) heavy metals concentrations in road side soils from selected locations in the Lagos metropolis, Nigeria

Baba A, A, Adekola F.A and Lawal A, (2009) trace metals concentration in road side dusts of Ilorin town

Babatunde Saheed Bada and Oladewa Titilope Oyegbami (2012) heavy metals concentrations in roadside dust of different traffic density in Abeokuta

Shakya Pawan Raj and Pradhananga Achut Ram (2013) determination and contamination 
assessment of $\mathrm{Pb}, \mathrm{Cd}$ and $\mathrm{Hg}$ in roadside dust along Kathmandu -bhaktapur road section of arniko highway, Nepal

Atayese, M.O.; Eigbadon, A.I.; Oluwa, K.A. \& Adesodun, J.K. (2009).Heavy metal contamination of amaranthus grown along major highways in Lagos..Afr. Crop. Sci. J.16:225-235

Fakayode, S.O. \& Olu-Owolabi, B.I. (2003) Heavy metal contamination of roadside topsoil in

Osogbo, Nigeria: its relationship to traffic density and proximity to ighways.EnvironmentalGeology.44:150-157.

Sukumar, A. and Subramanian, R. (2003). Relative element levels in paired samples of scalp hair and fingernails of patients from New Delphi. Science of the Total Environment 372: 474-479.

Wilhelm, M., Ebervein, G., Holzer, J., Sugiri, D., Gladtke, D. and Ranft, U.(2007). Human biomonitoring of $\mathrm{Cd}$ and $\mathrm{Pb}$ exposure of child mother pair from Germany living in the vicinity of industrial (Hot Pot NRW). Journal of Trace Elements in Medicine and Biology 19: 83-90.

Wilhem, M. and Hafner, D. (1993). Monitoring of Cd, $\mathrm{Cu}, \mathrm{Pb}$ and $\mathrm{Zn}$ status in young children using toenails, comparison with scalp hair. Science of the Total Environment 103: 1999-2007.
Ward, N. I., Spyrou, N. M and Damyanova, A. A (1988).Study of hair element content from an urban Bulgaria population using NAA assessment of environmental status. J. Radianal Nucl. Chem. 114: 125-135

Um-e-Ammara Shan and Nahhed ikram (2012) heavy metals in human scalp hair and nail samples from Pakistan: influence of working and smoking habits

Wolfsperger Hauser G, Walter G, Schlagenhaufen C.1994.heavy metals in human hair samples from Austria and Italy: influence of sex and smoking habits. The science of the total environmental 156:235-242.

Birungi Z., Masola, B., Zaranyika, M.F., Naigaga, I., Marshall, B., 2007.Active biomonitoring of trace heavy metals using fish (Oreochromis niloticus) as bioindicator 